Dem dienen auch die flüssig geschriebenen kurzen Einführungen in die regionalen Menschenrechtssysteme, die dem Leser das Verständnis für die Rahmenbedingungen der Konventionen erleichtern, teils aber in ihrer Kürze Sachverhalte sehr vereinfachen müssen. So erscheint etwa die detaillierte Hervorhebung der Homogenität der Vertragsstaaten der Europäischen Menschenrechtskonvention (EMRK) nahezu wie eine Beschreibung der Gründungsstaaten der Europäischen Gemeinschaften; an anderer Stelle wird im Rahmen der Darstellung des Menschenrechtsschutzes der Europäischen Gemeinschaften einerseits die Bedeutung des Vorlageverfahrens nach Artikel 177 EWG-Vertrag für die Kontrolle von Menschenrechtsverletzungen (das nach dem Solange II-Beschluß des Bundesverfassungsgerichts [BVerfGE 73, $340 \mathrm{ff}$.] gerade auch für die Bundesrepublik an Gewicht gewonnen hat) verkannt und die Bedeutung der nationalen Grundrechte der Mitgliedstaaten für den sog. „Marktbürger" auf internationaler Ebene andererseits übersehen. Diese Beispiele entwerten jedoch die Übersicht keineswegs, da sie für ihren Zweck der Einführung kurz und notgedrungen unvollständig bleiben muß. Positiv jedenfalls die überschaubare, insbesondere aber gründlich ausgewählte und thematisch geordnete Kurzbibliographie.

Unklar bleibt, weswegen etwa Protokoll Nr. 6 zur EMRK über die Abschaffung der Todesstrafe vom 28. 4. 1983 nicht aufgenommen wurde. Bezüglich der Protokolle Nr. 7 und 8 ließe sich zwar einwenden, daß sie noch nicht in Kraft getreten sind, aber auf Protokoll Nr. 8 wird verhältnismäßig eingehend rekuriert, so daß der Text sicherlich nicht überflüssig wäre.

Als handliches und - auch das ist nicht unerheblich - erschwingliches Taschenbuch wird es einer breiten Öffentlichkeit einen Einblick in den regionalen Menschenrechtsschutz verschaffen.

UlfMarzik

\title{
The International Law of Human Rights in Africa
}

Basic Documents and Annotated Bibliography

compiled by M. Hamalengwa, C. Flinterman and E. V. O. Dankwa

Dordrecht, Boston, London: Martinus Nijhoff Publishers, 1988, 427 pp., $£ 43.50$

The $40^{\text {th }}$ anniversary of the adoption of the Universal Declaration of Human Rights of the United Nations by the General Assembly (A/ RES/ 217 (III) of 10 December 1948) has stimulated the idea to lay special emphasis on the evolution and the condition of human rights in this issue of VRÜ, just as it has inspired a variety of recent publications in the field of human rights.

The editors of the present book, however, by compiling documents forming the foundation for the African Charter on Human and Peoples' Rights (Banjul Charter of 1981), do not only intend to trace back the roots of this latest regional human rights instrument to the Universal Declaration of 1948 . Their intention is, furthermore, to point out that the history 
of human rights in Africa has even deeper, and especially also African roots. This view is supported by the Preamble of the African Charter which recalls, inter alia, the "virtues of their [the African countries'] historical tradition and the values of African civilization". Yet, due to the lack of earlier written human rights documents of African origin, the chapter on African international law comprises only documents that date back some thirty years. For details on earlier aspects of African human rights history, the editors merely refer to the bibliography in Part V of the book. This is one of the instances that questions arising are left unanswered.

Indeed, the primary objective for the promotion of this book has been to provide the documents, i.e. conventions, resolutions, declarations and recommendations, which form the basis for the comprehension and application of the 1981 Banjul Charter, especially to promote studies of human rights and, finally, to facilitate the mandate (Art. 45) of the African Commission on Human and Peoples' Rights set up under Article 30 of the Charter. Therefore, introductory background information and a survey of the discussion regarding the interpretation of the provisions of the instruments and their evaluation, have been omitted. For topics like the evolution of human rights in early Africa, however, for which documents do not provide a source of information, a short introduction would have served the purpose of the book well.

This selection of documents is primarily directed towards international human rights practice and study within Africa itself. That is the main reason for the European reader to miss some guidance or suggestions for deeper study on the relationship towards the European and American human rights system and - as a result from a such comparative legal survey - an evaluation of the distinct features of the Banjul Charter. However, not only from the African standpoint the characteristic features of rights and duties, individual and collective rights and, last but not least, the lack of a strong enforcement institution rather justify a thorough study of the close interrelationship between the Banjul Charter and the Charter of the Organization of African Unity (OAU) of 1963.

As the support for the struggle of the African majority against the degrading Apartheid policy of the South African government and against the continued presence of South Africa in Namibia has been the cornerstone of a common African attitude towards human rights, it is fitting and proper to dedicate a section on instruments concerning Southern Africa, including the 1970 Advisory Opinion of the International Court of Justice on Namibia. Whereas the encroachment on minimum standards of human dignity by Apartheid helped to form an African consent on a "first " minimum standard of human rights, the Banjul Charter was born out of the conviction that human rights had to be safeguarded on an international African scale and that there is no room for "double standards", i.e. the concealment of human rights violations within the country by criticism of violations elsewhere.

The long list of United Nations instruments of general international law of human rights resembles the fruitful inspirations Africa gained from the work of the General Assembly for the promotion of human rights. Since the editorial work has been finished in early 1987, the Declaration on the Right to Development, adopted by the General Assembly on 4 December 1986 (A/ RES/ 41/128), has not been included in this selection. It must be for the 
same reason that the coming into force of the Banjul Charter in October 1986 is only mentioned in a footnote of the Preface.

The book contains a bibliography of French and English titles on human rights in general and as special section with publications dealing with aspects of human rights in Africa. The selection comprises early and recent monographs and articles, however, it may not be called complete. For its practical use it would have been of advantage to structure the information by topics. Here again, short introductory essays would have allowed a guided structure of the literature available on each of the subjects. It is convenient to find a table of the status of ratifications and the wording of the reservations of the African countries as appendices of the book. Altogether, this selection of relevant documents will be a valuable source for first hand studies on the status of human rights in Africa.

Ulf Marzik

\section{Armin Barthel}

\section{Entwicklung und Menschenrechte:}

\section{Das Recht auf Entwicklung als Menschenrecht}

Aachener Studien Sozialwissenschaften, Band 1, hrsg. von: Winfried Böttcher, Rader Verlag, Aachen 1986, 121 Seiten, DM 19,80.

Das Recht auf Entwicklung bezieht aus der Verbindung der Bereiche Menschenrechte und Entwicklung sowohl seine Attraktivität für die einen als auch seine Fragwürdigkeit für die anderen. Während die Entwicklungsländer darin eine Chance für einen Legitimationsgewinn ihrer Forderung nach einer Neuen Internationalen Weltwirtschaftsordnung erwarten, ist die Haltung der Industrieländer eher skeptisch darauf gerichtet, daß durch die seit Anfang der 70er Jahre währende Diskussion um das "Menschenrecht auf Entwicklung « nicht der gesicherte Bestand an Menschenrechten in den Hintergrund gedrängt wird. Bei den Kontrahenten dieser Auseinandersetzung ist die Bedeutung eines interdisziplinären Ansatzes zur Lösung der mit diesem Themenkomplex verbundenen komplizierten Fragen weithin anerkannt.

Eines solchen modi operandi bedient sich auch der Soziologe Armin Barthel im ersten Band einer neuen sozialwissenschaftlichen Publikationenreihe der Technischen Hochschule Aachen. Der Autor setzt sich einleitend zum Ziel, den Zusammenhang von Entwicklung und Menschenrechten anhand einer Analyse des "Rechts auf Entwicklung als Menschenrecht “ zu erschließen. Daß ein derart weitgestecktes, aber nur auf 112 Textseiten angelegtes Unterfangen notwendig fragmentarischen Charakter haben muß, leuchtet ein. Der Autor hofft demnach, seine Abhandlung möge das in bezug auf das Recht auf Entwicklung noch feststellbare Dunkel ein wenig erhellen.

Die Arbeit stellt in ihrem ersten "theoretischen« Teil die Geschichte des Entwicklungsbegriffes, seine völkerrechtliche Inbezugnahme sowie die Schwierigkeiten der Völkerrechts- 